\title{
Perlindungan Hukum terhadap Hak Anak Korban Pemerkosaan dalam Lingkungan Keluarga
}

\author{
Hana Aulia Putri \\ Magister Ilmu Hukum Universitas Islam Indonesia Yogyakarta Indonesia \\ Jln. Cik Di Tiro No. 1, Yogyakarta, Indonesia 55223 \\ hana_auliaputri22@yahoo.com
}

\begin{abstract}
This study aims to analyze the legal protection of the rights of child victims of rape in the family environment. This is a normative legal research that uses the concept of law as a principle of justice in the moral system and as a rule in legislation. The results of this study show that there are still many cases of rape in the family environment where children become victims which exhibits evidence of weak legal protection for children as victims of rape in families in Indonesia. The government has an obligation to provide special protection for child victims, including the fulfillment of the rights of child victims of rape in the family environment.
\end{abstract}

Keywords: Children rights; legal protection; rape in family

\begin{abstract}
Abstrak
Penelitian ini bertujuan untuk menganalisis perlindungan hukum terhadap hak anak korban perkosaan dalam lingkungan keluarga. Penelitian ini merupakan penelitian hukum normatif yaitu menggunakan konsep hukum sebagai asas keadilan dalam sistem moral dan sebagai kaidah dalam perundangundangan. Hasil penelitian ini menyimpulkan masih banyaknya kasus pemerkosaan dalam lingkungan keluarga dimana anak menjadi korban merupakan bukti lemahnya perlindungan hukum terhadap anak sebagai korban pemerkosaan dalam keluarga di Indonesia. Pemerintah memiliki kewajiban untuk memberikan perlindungan khusus kepada anak, termasuk pemenuhan hak anak korban pemerkosaan dalam lingkungan keluarga.
\end{abstract}

Kata-kata Kunci: Hak anak; perlindungan hukum; pemerkosaan dalam lingkungan keluarga 


\section{Pendahuluan}

Hukum sebagai kaedah bermakna endapan kesadaran sebagaimana seharusnya manusia hidup bermasyarakat yang ditujukan untuk menyelenggarakan kedamaian, keadilan, dan kebahagiaan bagi seluruh masyarakat. ${ }^{1}$ Ketika hukum dan moralitas bertentangan satu sama lain, warga negara dihadapkan pada pilihan pahit, yaitu kehilangan cita rasa moral mereka atau kehilangan penghormatan mereka kepada hukum. Dua keburukan ini memiliki dampak yang sama dan akan sulit bagi seseorang untuk memilih di antara keduanya. ${ }^{2}$

Kesadaran hukum sebagai buah dari budaya hukum dapat menimbulkan keyakinan seseorang bahwa menaati hukum bukan hanya takut dikenakan sanksi, tetapi juga didasarkan oleh keyakinan bahwa apabila ia melanggar hukum, maka ia merasakan adanya pelanggaran terhadap hak-hak manusia lain. ${ }^{3}$ Pelanggaran-pelanggaran terhadap hak asasi manusia membuktikan masih kurangnya kepedulian terhadap sesama manusia. Dari sekian banyak pelanggaran hak asasi manusia yang terjadi, tidak sedikit pula pelanggaran hak asasi tersebut terjadi terhadap anak-anak. Anak adalah seseorang yang belum berusia 18 tahun, termasuk anak yang masih dalam kandungan. ${ }^{4}$

Beberapa tahun belakangan ini, media massa makin dihiasi oleh banyaknya tindak pidana pemerkosaan terhadap anak yang dilakukan dalam lingkungan keluarga yang terjadi di berbagai daerah di Indonesia. Pemerkosaan yang terjadi dalam lingkungan keluarga seperti ayah kandung memperkosa anak kandung, ayah tiri memperkosa anak tiri dan sebagainya. Terkait hal ini, terkadang anak sebagai korban tidak mendapatkan perlindungan hukum meskipun pelaku sudah dikenai pidana penjara. Pemulihan korban merupakan sesuatu yang juga sangat penting mengingat anak sebagai korban pemerkosaan juga mempunyai hak yang sama seperti anak-anak pada umumnya di mata hukum. Setiap anak merupakan anugerah dari Tuhan Yang Maha Esa yang dijamin hak-hak dan kewajibannya semenjak dalam kandungan, yang harus dididik, dibesarkan dengan penuh kasih sayang, dirawat dan dijaga dari segala hal buruk yang dapat membahayakan hidupnya, serta dilengkapi segala kebutuhannya. Hal tersebut seharusnya menjadi pegangan oleh setiap orang tua maupun keluarga dalam menjamin

\footnotetext{
1 Erdiansyah, "Kekerasan Dalam Penyidikan Dalam Perspektif Hukum dan Keadilan", Jurnal Ilmu Hukum, Fakultas Hukum Universitas Riau, Vol. 1, No. 1 Agustus 2010, hlm. 94.

${ }^{2}$ Frederic Bastiat, Hukum, Rancangan Klasik. Untuk Membangun Masyarakat Merdeka, Freedom Institute, Jakarta, 2010, hlm. 9.

3 Waluyadi, Kejahatan, Pengadilan dan Hukum Pidana, Mandar Maju, Bandung, 2009, hlm. 98.

${ }^{4}$ Berdasarkan Pasal 1 angka 1 Undang-Undang Nomor 23 Tahun 2002 tentang Perlindungan Anak
} 
terjaganya hak-hak anak dan bentuk syukur atas anugerah yang telah diberikan oleh Tuhan Yang Maha Esa.

Banyaknya kasus pemerkosaan terhadap anak yang masih di bawah umur membuktikan salah satu indikator buruknya kualitas perlindungan terhadap anak di Indonesia. Keluarga yang seharusnya menjadi tempat berlindung bagi anak, karena keberadaan anak yang belum mampu untuk hidup sendiri tentunya masih sangat membutuhkan orang lain terutama keluarga untuk berlindung, mendapatkan rasa aman, dan tempat pencipta kebahagiaan. Selain itu, negara juga bertanggung jawab dalam menjamin terpenuhinya hak-hak anak korban perkosaan terutama yang terjadi dalam lingkungan keluarga mengingat pemulihan terhadap korban merupakan salah satu hal yang sangat penting namun seringkali terabaikan setelah proses peradilan selesai.

\section{Rumusan Masalah}

Bagaimana perlindungan hukum terhadap hak anak korban perkosaan dalam lingkungan keluarga?

\section{Tujuan Penelitian}

Berdasarkan uraian di atas, maka tujuan penelitiannya adalah untuk mengetahui perlindungan hukum terhadap hak anak korban perkosaan dalam lingkungan keluarga?

\section{Metode Penelitian}

Penelitian ini merupakan penelitian hukum normatif yang mengkaji konsep hukum sebagai asas keadilan dalam sistem moral dan sebagai kaidah dalam perundang-undangan, khususnya aspek kebijakan hukum pidana dan perlindungan hukum terhadap anak korban pemerkosaan dalam keluarga. Metode pendekatan penelitian yang digunakan dalam penelitian ini adalah pendekatan perundang-undangan dan pendekatan konseptual.

\section{Hasil Penelitian dan Pembahasan}

Tujuan mendapatkan perlindungan hukum adalah terciptanya ketertiban dan ketentraman diantara nilai dasar dari hukum, yaitu adanya kepastian hukum, kegunaan hukum, serta keadilan hukum dimana ketiga nilai dasar tersebut diharapkan dapat tercapai bersama. ${ }^{5}$ Terkait hal ini, Fitzgerald mengutip istilah

${ }^{5}$ John Thamrun, Perselisihan Prayudisial (Penundaan Pemeriksaan Perkara Pidana Terkait Perkara Perdata), Sinar Grafika, Jakarta, 2016, hlm. 27. 
teori perlindungan hukum dari Salmond bahwa hukum bertujuan mengintegrasikan dan mengkoordinasikan berbagai kepentingan dalam masyarakat karena dalam suatu lalu lintas kepentingan, perlindungan terhadap kepentingan tertentu dapat dilakukan dengan cara membatasi berbagai kepentingan di lain pihak.

Kepentingan hukum adalah mengurusi hak dan kepentingan manusia sehingga hukum memiliki otoritas tertinggi untuk menentukan kepentingan manusia yang perlu diatur dan dilindungi. Perlindungan hukum harus melihat tahapan yakni perlindungan hukum lahir dari suatu ketentuan hukum dan segala peraturan hukum yang diberikan oleh masyarakat yang pada dasarnya merupakan kesepakatan masyarakat tersebut untuk mengatur hubungan perilaku antara anggota masyarakat dan perseorangan dengan pemerintah yang dianggap mewakili kepentingan masyarakat. ${ }^{6}$

Pengertian perlindungan hukum menurut Satjipto Raharjo adalah memberikan pengayoman terhadap Hak Asasi Manusia (HAM) yang dirugikan orang lain dan perlindungan itu diberikan kepada masyarakat agar dapat menikmati semua hak-hak yang diberikan oleh hukum. ${ }^{7}$ Perlindungan hukum di Indonesia masih terbilang sedikit lemah mengingat banyak kasus yang terjadi masih kurang mendapatan perlindungan hukum salah satunya yaitu tentang kasus pemerkosaan anak dibawah umur, meskipun perlindungan hukum itu sudah tercantum dalam Undang-Undang Dasar 1945 atau peraturan lainnya yang menjamin adanya perlindungan hukum terhadap anak korban pemerkosaan. Banyak kasus pemerkosaan terhadap anak yang terlapor di Indonesia tetapi tidak sedikit pula kasus pemerkosaan yang tidak terlapor. Alasannya karena banyak anak yang diancam dan diintimidasi untuk tidak mengaku atas apa yang dialaminya, korban dan keluarga takut akan adanya stigmatisasi lingkungan sehingga enggan untuk melapor, yang terkadang pada akhirnya berpengaruh terhadap psikis sang anak.

Beberapa kasus pemerkosaan terhadap anak yang terjadi di Indonesia beberapa tahun ini didominasi oleh kasus pemerkosaan terhadap anak dalam lingkungan keluarga. Anak-anak yang masih di bawah umur yang seharusnya mendapatkan perlindungan dari segala hal yang dapat membahayakan dirinya terutama dari keluarga sebagai orang terdekat dan orang pertama tempat anak memperoleh perlindungan, harusnya menjadi benteng terdepan dari setiap ancaman, tekanan, kekerasan, dan hal-hal yang dapat membahayakan dirinya bukan sebagai tempat menyeramkan dan penghancur masa depan. Kasus

${ }^{6}$ Satjipto Raharjo, Ilmu Hukum, PT. Citra Aditya Bakti, Bandung, 2000, hlm. 53.

${ }^{7}$ Ibid., hlm. 69. 
pemerkosaan terhadap anak dalam lingkungan keluarga akan berbeda dengan kasus pemerkosaan terhadap anak di luar lingkungan keluarga.

Pemerkosaan terhadap anak dalam lingkungan keluarga biasanya memberikan traumatik yang berlangsung lama, bahkan ada yang terjadi hingga bertahun-tahun lamanya. Hal ini dikarenakan beberapa faktor yang menyebabkan itu terjadi, seperti ketidakberdayaan dan posisi korban yang masih ketergantungan terhadap keluarga karena korban masih terbilang anak-anak yang mudah dilema dan tak berdaya. Selain itu, pelaku dalam hal ini menggunakan berbagai cara untuk memperdaya korban, menekan, dan mengancam korban bahkan nekat mengancam akan membunuh korban, sehingga korban merasa ketakutan dan tidak memiliki kekuatan untuk melawan.

Berdasarkan keterangan di atas, perlu adanya perlindungan hukum mengenai jaminan atas ketersediaan akses bagi korban pada pemulihan kesehatan biologis, psikologis, maupun keterjaminan dalam pergaulan secara sosial, yaitu bagaimana mereka berhadapan dengan teman-temannya dan bagaimana mereka akan menghadapi orang luar yang mengetahui apa yang mereka alami. Mengingat tindak pidana perkosaan merupakan salah satu tindak pidana yang sangat mencemaskan terlebih lagi yang menjadi korban adalah anak-anak di bawah umur dimana hal ini akan mempengaruhi psikologis dan perkembangan dari anak tersebut bahkan menimbulkan trauma seumur hidup. Terkadang halhal tersebut sering terabaikan sebagai hak yang seharusnya bisa diperoleh oleh anak korban pemerkosaan. Belum lagi pemberitaan media massa yang akan menjadi jejak digital yang memiliki dampak negatif terhadap keberlangsungan hidupnya di masa yang akan datang.

Perlindungan hukum terhadap anak termasuk anak korban perkosaan dalam lingkungan keluarga telah tercantum dalam Undang-Undang Dasar 1945 yaitu Pasal 28B ayat (2) UUD 1945, berbunyi: "Setiap anak berhak atas kelangsungan hidup, tumbuh, dan berkembang serta berhak atas perlindungan dari kekerasan dan diskriminasi." Selain itu, ditegaskan dalam Pasal 28D ayat (1) UUD 1945, berbunyi: "Setiap orang berhak atas pengakuan, jaminan, perlindungan, dan kepastian hukum yang adil serta perlakuan yang sama dihadapan hukum." Selain itu, berdasarkan Pasal 58 ayat (1) Undang-Undang Nomor 39 Tahun 1999 tentang Hak Asasi Manusia (UU HAM) menyatakan bahwa setiap anak berhak untuk mendapatkan perlindungan hukum dari segala bentuk kekerasan fisik atau mental, penelantaran perlakuan buruk, dan pelecehan seksual selama dalam pengasuhan orang tua atau walinya, atau pihak lain maupun yang bertanggung jawab atas pengasuhan anak tersebut. Ayat (2) pasal tersebut mengatur bahwa dalam hal orang tua, wali, atau pengasuh anak 
melakukan segala bentu penganiayaan fisik atau mental, penelantaran, perlakuan buruk, dan pelecehan seksual termasuk pemerkosaan, dan atau pembunuhan terhadap anak yang seharusnya dilindungi, maka harus dikenakan pemberatan hukuman. Selain itu, Pasal 65 UU HAM menyatakan bahwa setiap anak berhak untuk memperoleh perlindungan dari kegiatan eksploitasi dan pelecehan seksual, penculikan, perdagangan anak, serta dari berbagai bentuk penyalahgunaan narkotika, psikotropika, dan zat aditif lainnya.

Berikut ini adalah beberapa contoh kasus pemerkosaan dalam lingkungan keluarga yang terjadi dan terungkap dalam kurun waktu 2019-2020, di antaranya yaitu:

Pertama, Polresta Tanggamus menahan tiga orang tersangka (ayah, kakak, dan adik kandung) pemerkosa berkali-kali anak kandung sekaligus saudari kandung sendiri AG, remaja disabilitas berusia 18 tahun, ahad (24/2). Aksi menyimpang tersebut dilakukan di rumahnya setelah ibu kandung korban meninggal. Bapak korban memperkosa anaknya karena melihat putri perempuannya dalam kondisi berkebutuhan khusus. Sedangkan kakak dan adik kandung korban melakukan perbuatan menyimpang tersebut karena terpengaruh setelah menonton video porno di dalam telepon genggamnya. Polisi menyebutkan, tindakan bejat tersebut dilakukan para tersangka dalam kurun waktu setahun belakangan. Bahkan, perbuatan terlarang tersebut sempat dilakukan pada 20 Februari 2019 oleh YG. Pemerkosaan terhadap remaja putri disabilitas tersebut dilakukan tersangka berkali-kali selama tahun 2018. Kejadian menggemparkan warga setempat, setelah kondisi korban yang kian hari sebelumnya gemuk menjadi kurus. Tetangga melaporkan kejadian tersebut kepada polisi. Aksi para tersangka tersebut terancam Pasal 81 ayat 3 Undang-Undang Nomor 17 Tahun 2016 tentang Perlindungan Anak (UU Perlindungan Anak). Ancaman hukuman penjara minimal 5 tahun dan maksimal 15 tahun. Setelah itu, para tersangka juga terancam sepertiga dari ancaman hukuman maksimal karena dilakukan orang tua sendiri, wali, dan orang-orang yang mempunyai ikatan keluarga atau sedarah. ${ }^{8}$

Kedua, AD (40), warga Kecamatan Bunut, Kabupaten Pelalawan, Riau, ditangkap polisi lantaran diduga melakukan pencabulan terhadap anak tirinya selama 6 tahun. Sejak korban berusia 13 sampai 18 tahun, senantiasa dipaksa pelaku. Kasus terungkap setelah korban didampingi oleh kakaknya melaporkan perbuatan ayah tirinya ke Polsek Bunut. Laporan korban langsung direspon polisi. AD berhasil diamankan, lalu diinterogasi. Pelaku mengaku telah melakukan persetubuhan terhadap korban berulang kali semenjak tahun 2015, hingga terakhir kali pada kamis 11 Juni 2020, sekitar pukul 22.00 WIB. Perbuatan itu dilakukan di dalam kamar korban. Kepada polisi, pelaku beralasan tidak merasa puas bila berhubungan badan dengan istrinya, ibu kandung korban. Ibu korban saat ini dalam keadaan sakit, sakit stroke sudah

8 Mursalin Yaslan, "Kronologi Kasus Pemerkosaan Bejat Satu Keluarga di Lampung", https://m.republika.co.id/amp/pngrh1377, diakses pada 19 Juli 2020, pukul 22.14 WIB. 
selama lebih kurang 1 tahun. Korban takut memberitahukan perilaku ayah tirinya, karena pelaku kerap mengancam supaya korban tidak melaporkan apa yang dialaminya. Jika korban berani untuk melaporkannya, maka pelaku akan membunuh korban dan menyakiti ibunya. Atas perbuatannya, AD dijerat Pasal 81 ayat (2), (3) UU RI Nomor 17 Tahun 2016 tentang Perubahan atas UU RI Nomor 23 Tahun 2002 Tentang Perlindungan Anak. ${ }^{9}$

Ketiga, seorang siswi Sekolah Menengah Pertama (SMP) inisial LL, di Kabupaten Mamasa, Sulawesi Barat (Sulbar), menjadi korban rudapaksa hingga hamil enam bulan. Parahnya lagi, pelajar 17 tahun ini dirudapaksa oleh keluarganya sendiri, mulai dari ayah, kakak hingga sepupunya. Gadis belia ini dirudapaksa satu keluarga sejak masih mengenyam pendidikan di bangku SD hingga SMP, sejak tahun 2016 hingga tahun 2020. Ketiga pelaku yang tega rudapaksa korban ini masing-masing, ayahnya bernama Mika, 59 tahun, kakaknya bernama Demma, 23 tahun, dan sepupunya bernama Daen, 22 tahun. Berdasarkan keterangan dari para pelaku dan korban, perbuatan bejat itu dimulai dari sang ayah. Dia merudapaksa putri mungilnya itu sejak ia masih duduk dibangku kelas VI SD 2016 lalu, di kebun miliknya, Dusun Tondok Oppo, Kelurahan Tawalian, Kecamatan Tawalian, Kabupaten Mamasa, Sulawesi Barat. Pada tahun 2017 silam, sepupu korban ini juga sempat mencabuli korban dengan awalnya hanya meraba bagian intin korban sampai akhirnya suatu waktu di tempat lain pelaku menyetubuhi korban. Saat itu korban masih duduk di bangku SMP, kejadian itu terjadi di rumah pelaku tahun 2017. Sementara untuk kakak kandung korban yakni Demma, juga tega merudapaksa adiknya itu sejak tahun 2017 lalu hingga tahun 2020. Demma ini sering melakukan persetubuhan dengan adik kandungnya meski telah hamil, dan terakhir ini ia melakukan perbuatan tak senonoh itu pada tanggal 23 Januari 2020. Sementara, para pelaku dijerat dengan UU Nomor 35 tahun 2014 tentang Perlindungan Anak, dengan ancaman hukuman maksimal 15 tahun penjara. ${ }^{10}$

Keempat, seorang remaja putri berinisial N (14) dengan didampingi orang tua melaporkan Kepala UPT. Pusat Pelayanan Terpadu Perlindungan Perempuan dan anak (P2TPA) Lampung Timur berinisial DA ke Polda Lampung. N mengaku diperkosa oleh DA. Pandra mengatakan remaja putri 14 tahun itu seorang pelajar. Dia berada di P2TP2A Lampung karena sebelumnya dicabuli oleh pamannya. N dicabuli pamannya itu pada Januari 2020. Orang tua korban lalu melapor ke Polres Lampung Timur dan dilakukan proses sidik UndangUndang Perlindungan Anak, diputuslah pada bulan Mei tahun 2020 kepada paman korban dihukum 13 tahun. Selama menjalani trauma healing di P2TP2A Lampung Timur, korban didampingi 2 petugas. Salah satunya DA. Jadi, selama itu tinggal di rumah si DA itu, itu ceritanya. Tidak tahu rumahnya seperti apa, pokoknya di dalam pengawasan DA supaya tidak trauma. Namun dalam masa

9 Abdullah Sani, Istri Stroke, "Suami di Pelalawan Cabuli Anak Tiri Selama 6 Tahun", https://m.merdeka.com/peristiwa/istri-sakit-stroke-suami-di-pelalawan-cabuli-anak-tiri-selama-6-tahun.html, diakses pada 19 Juli 2019, pukul 23.47 WIB.

${ }^{10}$ Eka Musriang, "Siswi SMP Sulbar Disetubuh Sekeluarga Hingga Hamil”, https://www.tagar.id/siswismp-sulbar-disetubuhi-sekeluarga-hingga-hamil, diakses pada 20 Juli 2020, Pukul 00.37 WIB. 
trauma healing itu, $\mathrm{N}$ mengaku kembali menjadi korban pencabulan. Dalam laporannya, pencabulan itu disebut terjadi pada akhir Juni 2020.11

Kasus-kasus di atas menunjukkan bahwa banyaknya kasus perkosaan terhadap anak dalam lingkungan keluarga. Hal ini membuktikan bahwa perlunya perlindungan terhadap anak korban pemerkosaan terutama dalam lingkungan keluarga. Seorang anak yang kehilangan kemerdekaan akibat perbuatan yang sengaja maupun tidak sengaja melanggar hukum berhak mendapatkan perlakuan khusus. Terlebih lagi seperti kasus-kasus di atas, anak berkebutuhan khusus yang diperkosa oleh ayah, kakak, dan adik kandungnya sendiri setelah ibu kandungya meninggal dunia, ayah tiri yang memperkosa anak tirinya, gadis belia ini dirudapaksa satu keluarga sejak masih mengenyam pendidikan dibangku SD hingga SMP, dan yang terakhir remaja putri yang diperkosa oleh kepala UPT. P2TP2A, dimana korban yang seharusnya mendapat perlindungan tetapi justru malah sebaliknya kembali diperkosa dan diancam, bahkan menjual korban kepada laki-laki lain. Trauma yang seharusnya bisa terobati malah menjadi bertambah karena perbuatan tercela yang dilakukan oleh oknum kepala UPT tersebut.

Lemahnya perlindungan terhadap korban pemerkosaan dan masih kurangnya peran pemerintah di dalamnya sehingga menambah catatan buruk mengenai penanganan dan perlindungan korban perkosaan di Indonesia terutama pemerkosaan dalam lingkungan keluarga yang memiliki trauma yang cukup berat karena dilakukan oleh keluarga sendiri dan terjadi di dalam rumahnya sendiri yang notabenya tempat pertama untuk mendapatkan kebahagiaan, kasih sayang yang cukup, berlindung dari segala hal buruk yang dapat membahayakan dirinya dan mengancam masa depannya, justru menjadi tempat menyeramkan dan penghancur masa depannya.

Pasal 6 Undang-Undang Nomor 31 Tahun 2014 tentang Perubahan atas Undang-Undang Nomor 13 Tahun 2006 tentang Perlindungan Saksi dan Korban menyatakan bahwa korban pelanggaran hak asasi manusia yang berat, korban tindak pidana terorisme, korban tindak pidana perdagangan orang, korban tindak pidana penyiksaan, korban tindak pidana kekerasan seksual, dan korban penganiayaan berat, selain berhak sebagaimana dimaksud dalam Pasal 5, juga berhak mendapatkan bantuan medis dan bantuan rehabilitasi psikososial dan psikologis yangdiberikan berdasarkan keputusan LPSK. Undang-Undang Nomor 17 Tahun 2016 tentang Penetapan Peraturan Pemerintah Pengganti UndangUndang Nomor 1 Tahun 2016 tentang Perubahan Kedua atas Undang-Undang

11 Idham Kholid, "Korban Perkosaan Paman Diduga Diperkosa Pejabat Perlindungan Anak di Lampung", http://m.detik.com/news/berita/d-5081600/korban-perkosaan-paman-diduga-diperkosa-pejabatperlindungan-anak-di-lampung? single $=1$, diakses pada 19 Juli 2020, pukul 14.44 WIB. 
Nomor 23 Tahun 2002 tentang Perlindungan Anak menjadi Undang-Undang juga mengatur tentang perlindungan terhadap anak korban perkosaan. Kekerasan seksual terhadap anak dari tahun ke tahun semakin meningkat dan mengancam peran strategis anak sebagai generasi penerus masa depan bangsa dan negara, sehingga perlu memperberat sanksi pidana dan memberikan tindakan terhadap pelaku kekerasan seksual terhadap anak.

Perlindungan anak dan kekerasan yang dilakukan terhadap anak juga telah dijelaskan dalam Pasal 1 angka 2 dan angka 15a Undang-Undang Perlindungan Anak bahwasannya perlindungan anak adalah segala kegiatan untuk menjamin dan melindungi anak dan hak-haknya agar dapat hidup, tumbuh, berkembang, dan berpartisipasi secara optimal sesuai dengan harkat dan martabat kemanusiaan, serta mendapat perlindungan dari kekerasan dan diskriminasi. Sedangkan kekerasan adalah setiap perbuatan terhadap anak yang berakibat timbulnya kesengsaraan atau penderitaan secara fisik, psikis, seksual, dan/atau penelantaran, termasuk ancaman untuk melakukan perbuatan, pemaksaan, atau perampasan kemerdekaan secara melawan hukum.

Pasal 21 Undang-Undang Perlindungan Anak juga menjelaskan tentang kewajiban dan tanggung jawab Negara, Pemerintah, dan Pemerintah Daerah yaitu pertama, Negara, Pemerintah, dan Pemerintah Daerah berkewajiban dan bertanggung jawab menghormati pemenuhan Hak Anak tanpa membedakan suku, agama, ras, golongan, jenis kelamin, etnik, budaya dan bahasa, status hukum, urutan kelahiran, dan kondisi fisik dan/atau mental. Kedua, untuk menjamin pemenuhan Hak Anak sebagaimana dimaksud pada ayat (1), negara berkewajiban untuk memenuhi, melindungi, dan menghormati Hak Anak. Ketiga, untuk menjamin pemenuhan Hak Anak, Pemerintah berkewajiban dan bertanggung jawab dalam merumuskan dan melaksanakan kebijakan di bidang penyelenggaraan Perlindungan Anak. Keempat, untuk menjamin pemenuhan Hak Anak dan melaksanakan kebijakan sebagaimana yang dimaksud pada ayat (3), Pemerintah Daerah berkewajiban dan bertanggung jawab untuk melaksanakan dan mendukung kebijakan nasional dalam penyelenggaraan Perlindungan Anak di daerah. Kelima, kebijakan tersebut dapat diwujudkan melalui upaya daerah membangun kabupaten/kota layak anak. Keenam, ketentuan lebih lanjut mengenai kebijakan kabupaten/kota layak anak diatur dalam Peraturan Presiden.

Pasal 22 UU Perlindungan Anak juga menjelaskan bahwa negara, pemerintah, dan pemerintah daerah berkewajiban dan bertanggung jawab memberikan dukungan sarana, prasarana, dan ketersediaan sumber daya manusia dalam penyelenggaraan perlindungan anak. Terkait hal ini, Pasal 23 menjelaskan bahwa Negara, Pemerintah, dan Pemerintah Daerah menjamin 
perlindungan, pemeliharaan, dan kesejahteraan Anak dengan memperhatikan hak dan kewajiban Orang Tua, Wali, atau orang lain yang secara hukum bertanggung jawab terhadap anak. Selain itu, Negara, Pemerintah, dan Pemerintah Daerah mengawasi penyelenggaraan Perlindungan Anak.

Pemerintah, Pemerintah Daerah, dan Lembaga negara lainnya berkewajiban dan bertanggung jawab untuk memberikan perlindungan khusus kepada anak termasuk mengenai anak korban kejahatan seksual sebagaimana yang telah tertera dalam Pasal 59 ayat (2) huruf j Undang-Undang Perlindungan anak ini. Pasal 69A juga mengatur bahwa Perlindungan Khusus bagi Anak korban kejahatan seksual sebagaimana dimaksud dalam Pasal 59 ayat (2) huruf $j$ dilakukan melalui upaya (1) edukasi tentang kesehatan reproduksi, nilai agama, dan nilai kesusilaan, (2) rehabilitasi sosial, (3) pendampingan psikososial pada saat pengobataan sampai pemulihan, dan (4) pemberian perlindungan dan pendampingan pada setiap tingkat pemeriksaan mulai dari penyidikan, penuntutan, sampai dengan pemeriksaan di sidang pengadilan.

Beberapa aturan tersebut seharusnya bisa menjadi acuan untuk penerapan keterjaminan selain perlindungan hukum terhadap proses peradilan dan juga keterjaminan perlindungan terhadap pemulihan fisik maupun psikis anak korban perkosaan. Hal ini terutama dalam lingkungan keluarga yang menimbulkan trauma yang lebih besar karena dilakukan oleh keluarga sendiri, yang notabennya orang paling terdekat, garda utama yang seharusnya menjadi tempat bergantung maupun berlindung dari berbagai kejahatan ataupun hal-hal yang dapat membahayakan kelangsungan hidup mereka.

Hidup bernegara dan bermasyarakat merupakan perikehidupan yang dapat langgeng oleh karena adanya nilai-nilai yang dipatuhi oleh segenap komponen dan/atau elemen dari unsur-unsur perilaku manusia yang ada di dalamnya. Nilai-nilai itu berakar lalu menjelma sebagai suatu sistem nilai yang dapat menjadi daya perekat dalam menjalin hidup bersama yang harmonis. ${ }^{12}$ Jika asas dan tujuan perlindungan dilaksanakan secara baik, bukan saja korban dan saksi yang mendapat perlindungan, tetapi lebih luas lagi. Tentu saja masyarakat, bangsa, dan negara terlindungi dan negara dianggap telah melaksanakan kewajibannya melindungi warganya dengan baik. Hal ini merupakan salah satu tujuan negara yang termaktub dalam Alinea 4 Pembukaan Undang-Undang Dasar Tahun 1945, yaitu “...Pemerintah Negara Indonesia yang melindungi segenap bangsa Indonesia dan seluruh tumpah darah Indonesia,..".13

12 Nurul Qomar, Hak Asasi Mnusia Dlam Negara Hukum Demokrasi (Human Rights in Democratiche Rechtsstaat), Sinar Grafika, Jakarta, 2014, hlm. 17-18.

13 Bambang Waluyo, Viktimologi Perlindungan Korban dan Saksi, Sinar Grafika, Jakarta, 2011, hlm. 39. 
Kasus pemerkosaan dalam keluarga banyak yang selesai ditangani dalam peradilan, tetapi tidak sedikit juga yang tidak mendapatkan bantuan pemulihan psikologis setelah proses peradilan selesai. Korban merupakan anak-anak yang harus melanjutkan masa depannya yang masih panjang yang memiliki trauma lebih berat karena pemerkosaan atau pelecehan seksual tersebut dilakukan oleh anggota keluarganya sendiri, kebanyakan kasus tersebut selesai tanpa adanya jaminan perlindungan dan pemulihan dari pemerintah setelah tersangka divonis bersalah dan dihukum.

Anak sebagai korban pemerkosaan terutama dalam lingkungan keluarga juga harus mendapatkan perhatian, perlindungan hukum, dan penanganan lebih lanjut terhadap apa yang telah dialaminya. Hal ini terutama pada proses pemulihan psikis yang diderita si korban untuk keberlangsungan hidup dan masa depannya yang masih panjang, karena anak merupakan salah satu aset yang sangat penting bagi suatu negara untuk melanjutkan peradaban dan pembangunan negara kedepannya, tetapi pada kenyataannya hak-hak yang seharusnya diperoleh oleh anak korban pemerkosaan dalam lingkungan keluarga sering terabaikan dan kurang mendapatkan perlindungan terutama perlindungan atas pemulihan terhadap psikis yang dialami oleh anak.

Banyak dari kasus yang terjadi sekarang ini masih kurang mendapatkan perhatian pemerintah dalam hal menjamin perlindungan hukum terhadap anak serta pemulihan psikis setelah dilakukannya proses hukum bagi pelaku. Banyak kasus yang masih belum terungkap serta terkadang setelah dilakukan proses hukum bagi pelaku, maka selesai pula kasus pemerkosaan tersebut. Padahal ada bagian yang juga sangat penting untuk dilakukan yaitu pemulihan psikis korban pemerkosaan dalam lingkungan keluarga ini, terlebih lagi jika korban hamil dan melahirkan dengan kondisi yang masih sangat muda, pemulihan psikis menjadi sangat penting untuk kelangsungan hidup keduanya, pemulihan identitas dari segala stigmanisasi masyarakat, pemulihan keberadaan keluarga yang sebelumnya pernah menimbukan trauma dalam hidupnya.

Selain itu, kasus tersebut juga memicu munculnya stigma-stigma dari masyarakat mengenai ketidakadilan dan kepercayaan masyarakat terhadap hukum. Masyarakat memandang bahwa kepastian hukum yang diharapkan dalam penerapannya juga tidak terlaksana dengan baik. Problematika antara kepastian hukum dan keadilan yang sering kali dipermasalahkan adalah ketidaksinergian. Sebenarnya, kedua-duanya harus mengalami pembaruan dan perubahan progresif melalui proses kreatif. Hal ini dikarenakan pelanggaran hukum dipicu oleh konflik antara masalah nilai-nilai peraturan dengan nilai-nilai keadilan. Menurut pandangan ini, hukum harus menjadi panglimanya sehingga 
persoalan antinomi, diskrepansi antara nilai-nilai hanya dapat diserasikan melalui penegakan hukum yang berlandaskan hukum yang ajeg dan nilai-nilai keadilan yang progresif. Kepastian hukum dan keadilan merupakan sekeping mata uang logam. ${ }^{14}$ Di samping itu, antara kepastian hukum, keadilan, dan kemanfaatan hukum sebenarnya interkoneksi atau interrelasi dengan peraturan hukum, perubahan hukum, dan harapan masyarakat akan bekerjanya hukum. ${ }^{15}$

\section{Penutup}

Masih banyaknya kasus anak sebagai korban pemerkosaan dalam keluarga yang terjadi sekarang ini menunjukkan lemahnya perlindungan hukum terhadap anak dan kurangnya peran pemerintah dalam memberikan perlindungan terhadap anak korban pemerkosaan dalam lingkungan keluarga tersebut. Pemerintah, Pemerintah Daerah, dan lembaga negara lainnya berkewajiban dan bertanggung jawab untuk memberikan perlindungan khusus kepada anak, termasuk mengenai anak sebagai korban pemerkosaan dalam lingkungan keluarga. Perlindungan hukum tersebut dapat dijalankan dengan berdasar pada beberapa peraturan perundang-undangan, yaitu Undang-Undang Nomor 17 Tahun 2016 tentang Penetapan Peraturan Pemerintah Pengganti Undang-Undang Nomor 1 Tahun 2016 tentang Perubahan Kedua atas Undang-Undang Nomor 23 Tahun 2002 tentang Perlindungan Anak, Undang-Undang Nomor 39 Tahun 1999 tentang Hak Asasi Manusia (UU HAM), dan Undang-Undang Nomor 31 Tahun 2014 tentang Perubahan atas Undang-Undang Nomor 13 Tahun 2006 tentang Perlindungan Saksi dan Korban.

\section{Daftar Pustaka}

\section{Buku}

Bastiat, Frederic, Hukum, Rancangan Klasik Untuk Membangun Masyarakat Merdeka, Freedom Institute, Jakarta, 2010.

Fahmi, Kepastian Hukum Mengenai Putusan Batal Demi Hukum dalam Sistem Peradilan Pidana Indonesi, PT. Ghalia Indonesia Publishing, Jakarta, 2018.

Matompo, Osgar S dan Muliadi dan Andi Nurul Isnawidiawinarti Achmad, Hukum dan Hak Asasi Manusia, Intrans Publishing, Malang, 2018..

Qomar, Nurul. Hak Asasi Mnusia Dlam Negara Hukum Demokrasi (Human Rights in Democratiche Rechtsstaat), Sinar Grafika, Jakarta, 2014.

Raharjo, Satjipto, Ilmu Hukum, PT. Citra Aditya Bakti, Bandung, 2000.

\footnotetext{
${ }^{14}$ Fahmi, Kepastian Hukum Mengenai Putusan Batal Demi Hukum dalam Sistem Peradilan Pidana Indonesia, PT. Ghalia Indonesia Publishing, Jakarta, 2018, hlm. 43.

15 Ibid., hlm.45.
} 
Thamrun, John, Perselisihan Prayudisial (Penundaan Pemeriksaan Perkara Pidana Terkait Perkara Perdata), Sinar Grafika, Jakarta, 2016.

Waluyadi, Kejahatan, Pengadilan, dan Hukum Pidana, Mandar Maju, Bandung, 2009.

Waluyo, Bambang, Viktimologi Perlindungan Korban dan Saksi, Sinar Grafika, Jakarta, 2011.

\section{Jurnal}

Erdiansyah, "Kekerasan Dalam Penyidikan Dalam Perspektif Hukum dan Keadilan", Jurnal Ilmu Hukum, Vol. 1, No. 1, Fakultas Hukum Universitas Riau, Agustus 2010.

\section{Media Elektronik}

Mursalin Yaslan, "Kronologi Kasus Pemerkosaan Bejat Satu Keluarga di Lampung", https://m.republika.co.id/amp/pngrh1377, diakses pada 19 Juli 2020, pukul 22.14 WIB.

Abdullah Sani, Istri Stroke, "Suami di Pelalawan Cabuli Anak Tiri Selama 6 Tahun", https://m.merdeka.com/peristiwa/istri-sakit-stroke-suami-dipelalawan-cabuli-anak-tiri-selama-6-tahun.html, diakses pada 19 Juli 2019, pukul 23.47 WIB.

Eka Musriang, "Siswi SMP Sulbar Disetubuh Sekeluarga Hingga Hamil", https:/ / www.tagar.id/siswi-smp-sulbar-disetubuhi-sekeluarga-hinggahamil, diakses pada 20 Juli 2020, pukul 00.37 WIB.

Idham Kholid, "Korban Perkosaan Paman Diduga Diperkosa Pejabat Perlindungan Anak di Lampung", http://m.detik.com/news/berita/d5081600/korban-perkosaan-paman-diduga-diperkosa-pejabatperlindungan-anak-di-lampung?single $=1$, diakses pada 19 Juli 2020, pukul 14.44 WIB.

\section{Perundang-undangan}

Undang-Undang Dasar Negara Republik Indonesia Tahun 1945

Undang-Undang Nomor 39 Tahun 1999 tentang Hak Asasi Manusia

Undang-Undang Nomor 31 Tahun 2014 tentang Perubahan atas Undang-Undang Nomor 13 Tahun 2006 tentang Perlindungan Saksi dan Korban

Undang-Undang Nomor 17 Tahun 2016 tentang Penetapan Peraturan Pemerintah Pengganti Undang-Undang Nomor 1 Tahun 2016 tentang Perubahan Kedua Atas Undang-Undang Nomor 23 Tahun 2002 tentang Perlindungan Anak Menjadi Undang-Undang 